\title{
A pathogen of New Zealand Pyropia plicata (Bangiales, Rhodophyta), Pythium porphyrae (Oomycota)
}

\author{
Nora Diehl ${ }^{1}$, Gwang Hoon Kim ${ }^{2}$ and Giuseppe C. Zuccarello, \\ ${ }^{1}$ Institute of Biological Sciences, University of Rostock, 18051 Rostock, Germany \\ ${ }^{2}$ Department of Biology, Kongju National University, Kongju 32588, Korea \\ ${ }^{3}$ School of Biological Sciences, Victoria University of Wellington, Wellington 6140, New Zealand
}

Geographic distributions of pathogens are affected by dynamic processes involving host susceptibility, availability and abundance. An oomycete, Pythium porphyrae, is the causative agent of red rot disease, which plagues Pyropia farms in Korea and Japan almost every year and causes serious economic damage. We isolated an oomycete pathogen infecting Pyropia plicata from a natural population in Wellington, New Zealand. The pathogen was identified as Pythium porphyrae using cytochrome oxidase subunit 1 and internal transcribed spacer of the rDNA cistron molecular markers. Susceptibility test showed that this Pythium from New Zealand was able to infect several different species and genera of Bangiales including Pyropia but is not able to infect their sporophytic (conchocelis) phases. The sequences of the isolated New Zealand strain were also identical to Pythium chondricola from Korea and the type strain from the Netherlands. Genetic species delimitation analyses found no support for separating $P$. porphyrae from $P$. chondricola, nor do we find morphological characters to distinguish them. We propose that Pythium chondricola be placed in synonymy with P. porphyrae. It appears that the pathogen of Pyropia, both in aquaculture in the northern hemisphere and in natural populations in the southern hemisphere is one species.

Key Words: Bangia; Bangiales; DNA barcoding; host specificity; Porphyra; Pythium chondricola; Rhodophyta; species delimitation; synonymization; taxonomy

\section{INTRODUCTION}

Aquaculture of marine algae is an important industry, especially in Asia. The production of seaweeds more than doubled between 2000 and 2012 (Food and Agriculture Organization of the United Nations 2014). The red alga Pyropia is the most consumed alga in the world, both for food and in the biomedical industry (e.g., porphyran, pycobilliproteins) (Gachon et al. 2010). In 2013, Pyropia made up about 1.8 million tons which is about $8 \%$ of the total global seaweed production, with values of US $\$ 1.2$ billion (FAO FishStat et al. 2016).
Pyropia cultivation losses amount to over US \$10 million annually from different diseases (Gachon et al. 2010, Blouin et al. 2011, Kim et al. 2014). Diseases like greenspot disease and Olpidiopsis blight as well as red-rot disease, result in a great decrease in productivity, yield and crop value (Kawamura et al. 2005, Klochkova et al. 2012, 2016b, Kim et al. 2014, 2016). With increasing farming intensity and increasing temperatures, caused by global warming, disease severity and occurrence is also expected to increase (Ding and Ma 2005, Gachon et al. 2010).

\section{(ब) (1) $(3$}

This is an Open Access article distributed under the terms of the Creative Commons Attribution Non-Commercial License (http://creativecommons.org/licenses/by-nc/3.0/) which permits unrestricted non-commercial use, distribution, and reproduction in any medium, provided the original work is properly cited.
Received January 17, 2017, Accepted February 25, 2017

*Corresponding Author

E-mail: joe.zuccarello@vuw.ac.nz

Tel: +64-4-463-6414, Fax: +64-4-463-5331 
The most common diseases of cultivated Pyropia are the red-rot disease and the "Olpidiopsis blight," caused by the oomycetes Pythium porphyrae M. Takah. \& M. Sasaki and Olpidiopsis pyropiae G. H. Kim \& T. A. Klochkova, respectively (Kim et al. 2014, Klochkova et al. 2016b). Algal pathogens of Pyropia have been reported for a closely related species, Pythium chondricola De Cock (Lee et al. 2015), an oomycete first described from Chondrus crispus Stackhouse in the Netherlands (De Cock 1986). These organisms are of particular concern as they are the main cause of harvest loss in China, Korea, and Japan (Kim et al. 2014). Red-rot disease alone leads to a yield reductions of up to $20 \%$ in farms in the Ariake Sea, Japan (Kawamura et al. unpublished data) and causes death of the host within a few days (Ding and Ma 2005).

Oomycota are fungal-like eukaryotes that are classified in the Stramenopiles (Patterson 1989). The genus Pythium is found throughout the world in freshwater, marine, and terrestrial habitats (Kageyama 2014, Klochkova et al. 2016a). Species delimitation is difficult in these microorganisms based solely on morphology, while accurate species delimitation is critical for nearly all biological applications. For example, incorrect names may lead to misguided efforts to eradicate two species while only one exists. This has led to the increased use of molecular data to identify and delimit species (e.g., Sandoval-Sierra et al. 2014, De la Bastide et al. 2015). Several methods have been developed to delimitate species using molecular data and to discover putative species, and a multipronged approach has been recommended as all methods are based on different assumptions (Leliaert et al. 2014). The application of names is further complicated by culture collections and DNA databases containing misassigned sequences (Sandoval-Sierra et al. 2014)

Pythium was first recorded on Porphyra tenera (now Pyropia tenera) in Japan (Arasaki 1947), but it still took three decades to designate the infective agent as Pythium porphyrae (Takahashi et al. 1977). Recent molecular studies, using mitochondria-encoded cytochrome oxidase subunit 1 (COI) and nuclear-encoded internal transcribed spacer of the rDNA cistron (ITS), have shown that Pythium consists of several well-supported clades with the marine species $P$. porphyrae and $P$. chondricola being closely related and in the same clade (clade A) (Lévesque and De Cock 2004, Robideau et al. 2011).

New Zealand offers diverse habitats for a range of $P y$ ropia and other closely related Bangiales, with more than 30 species found there (Nelson et al. 2006, Sutherland et al. 2011). Little is known about Pythium infection in Pyropia in natural habitats, even though the organism is well investigated in aquacultural settings (e.g., Park et al. 2000, Kawamura et al. 2005, Kim et al. 2014). A few studies have explored the host-range of Pythium in marine algae (e.g., Klochkova et al. 2016a) and generally indicate that they can have wide host ranges. Due to the wide variety of host substrate-specific relationships and their huge economic impact, the clarification of host-parasite relationships and proper identification of these pathogens is warranted.

We isolated a Pythium species infecting Pyropia plicata W. A. Nelson in Wellington, New Zealand and performed susceptibility tests using diverse algae, especially species of Bangiales. Species delimitation analysis and morphological investigation showed that synonimization between Pythium porphyrae and P. chondricola is necessary.

\section{MATERIALS AND METHODS}

\section{Sampling and isolation}

All samples of Pyropia plicata were collected at Moa Point Wellington, New Zealand (41 ${ }^{\circ} 20^{\prime} 31.6^{\prime \prime}$ S, 174 $48^{\prime} 35.4^{\prime \prime}$ E) on three different days: Jun 2, Jun 9, and Jul 5, 2016. The blades were checked for infection under the dissecting microscope. Sections that were infected were cut out (approximately $5 \times 5 \mathrm{~mm}$ ) and placed in wells with sterilized Provasoli's Enriched Seawater (1/4 strength PES, 36 PSU) (West and McBride 1999), to which a few drops of $\mathrm{GeO}_{2}$ (25 $\mu \mathrm{g} \mathrm{mL}^{-1}$ ) and a few mg of Penicillin were added. The 6 -well-boxes with the samples were maintained in an incubator at $15^{\circ} \mathrm{C}$ and $12: 12$ light : dark cycle $\left(20 \mu \mathrm{mol} \mathrm{m}{ }^{-2}\right.$ $\left.\mathrm{s}^{-1}\right)$. Once a week the medium was changed. Every three to five days uninfected Pyropia plicata tissue, which was collected from the same location, was added to maintain the cultures.

To isolate the oomycete from the algal tissue, the tissue was briefly wiped with either ethanol (70\%) or commercial bleach $(0.5 \%)$ to clean the surface of potential contaminants. The tissue was then placed in either flasks containing $100 \%$ cornmeal-seawater medium or on $50 \%$ and $100 \%$ cornmeal-seawater agar plates. The seawatercornmeal medium was prepared as follows: 50 g of organic cornmeal was added to an equal amount of sterile seawater (36 psu) and heated to boiling. After simmering for $10 \mathrm{~min}$, the solution was cooled and allowed to settle, it was filtered through cheese cloth and autoclaved. Before adding oomycetes, $200 \mu \mathrm{L}$ of streptomycin $\left(10 \mathrm{mg} \mathrm{mL}^{-1}\right.$ ethanol) and $200 \mu \mathrm{L}$ of rifampin ( $4.5 \mathrm{mg} \mathrm{mL}^{-1}$ methanol) were added to every $50 \mathrm{~mL}$ of medium. Agar plates were 
made with $50 \%$ and $100 \%$ seawater with $17 \mathrm{~g} \mathrm{~L}^{-1} \mathrm{BBL}$ Corn Meal Agar (BD Biosciences, Auckland, New Zealand), autoclaved and poured into plastic petri dishes. Before inoculation the plates were spread with $100 \mu \mathrm{L}$ of streptomycin $\left(10 \mathrm{mg} \mathrm{mL}^{-1}\right.$ ethanol) and $100 \mu \mathrm{L}$ of rifampin (4.5 $\mathrm{mg} \mathrm{mL} \mathrm{m}^{-1}$ methanol) to prevent bacterial growth (Francis et al. 2016). The plates and flasks, after inoculation, were kept in an incubator at $15^{\circ} \mathrm{C}$.

To induce reproduction in Pythium, we prepared Arasaki B Medium (Arasaki et al. 1968) and added the isolated hyphae from the agar plates or cornmeal media to the solution. These cultures were incubated at $20^{\circ} \mathrm{C}$.

\section{Host specificity}

For infection and host specificity experiments, different algae were collected at Moa Point, Wellington. Newly collected healthy tissue of Pyropia plicata (the original host) and various other algae (Table 1) were added individually to Pyropia plicata infected with Pythium and placed together in wells with sterilized $1 / 4$ strength PES, with added $\mathrm{GeO}_{2}\left(25 \mu \mathrm{g} \mathrm{mL}^{-1}\right)$ and Penicillin, and incubated at $15^{\circ} \mathrm{C}$ and $12: 12$ light : dark cycle $\left(20 \mu \mathrm{mol} \mathrm{m}^{-2}\right.$ $\left.\mathrm{s}^{-1}\right)$ for up to 2 weeks. Cultured conchocelis stages were also tested for infectivity (from Wendy Nelson, National Institute of Water and Atmospheric Research, Wellington, New Zealand) (Supplementary Table S1). Tissue was monitored microscopically every two to three days. All microscopic observations were made with a Olympus microscope (BX63 F; Olympus, Tokyo, Japan) and attached DB80 Camera.

\section{Molecular identification}

The Bangiales were extracted using the Chelex extraction method (Goff and Moon 1993). The oomycetes were extracted using a modified cetyltrimethylammonium bromide (CTAB) extraction method (Zuccarello and Lokhorst 2005). DNA was stored at $-20^{\circ} \mathrm{C}$.

To molecularly identify the Bangiales, we used the large subunit ribulose-bisphosphate carboxylase / oxygenase $(r b c \mathrm{~L})$ gene. $R b c \mathrm{~L}$ was amplified in two parts: part 1 using primers F145 (Kim et al. 2010) and R753 (Freshwater and Rueness 1994); and part 2 using primers F753 and R-rbcSstart (Freshwater and Rueness 1994). For the amplification of Pythium, two different primer pairs were used: the oomycete specific COI primers (forward OomCoxl-Levup, reverse OomCoxl-Levlo), and occasionally an alternate reverse primer, Fm85mod (Robideau et al. 2011) and for the ITS the universal primers, ITS1 and ITS4 (White et al. 1990).

The polymerase chain reaction (PCR) reaction volume was $30 \mu \mathrm{L}$, containing $1 \times$ reaction buffer (Bioline Reagents Ltd., London, UK), $0.2 \mu \mathrm{M}$ dNTP's, $2.5 \mathrm{mM} \mathrm{MgCl}_{2}, 0.033 \%$ BSA, each 0.25 pmol of forward and reverse primer, $1 \mathrm{U}$ BIOTaq DNA Polymerase (Bioline Reagents Ltd.) and 1 $\mu \mathrm{L}$ of template DNA. The PCR program (PTC-100; MJ Research Inc., Watertown, MA, USA) was $5 \mathrm{~min}$ at $95^{\circ} \mathrm{C}$, followed by $1 \mathrm{~min}$ at $94^{\circ} \mathrm{C}, 1 \mathrm{~min}$ annealing, $1 \mathrm{~min}$ at $72^{\circ} \mathrm{C}$ for 36 cycles and final extension step for $5 \mathrm{~min}$ at $72^{\circ} \mathrm{C}$. The annealing temperature for the $r b c \mathrm{~L}$ primers was $45^{\circ} \mathrm{C}$, for the COI primers $53^{\circ} \mathrm{C}$ and for the ITS primers $50^{\circ} \mathrm{C}$. The PCR products were electrophoresed in $1.0 \%$ agarose gels and visualized using ethidium bromide. Samples of appropriate size and intensity were prepared for sequencing using ExoSAP-IT following standard protocols (USB product; Affymetrix, Santa Clara, CA, USA). Sequencing was done commercially (Macrogen Inc., Seoul, Korea).

\section{Phylogenetics}

Forward and reverse sequences were assembled, edited and consensus sequences were generated in Geneious 9.1 (http://www.geneious.com) (Kearse et al. 2012). To confidently identify the Bangiales collected, newly generated large subunit ribulose-bisphosphate carboxylase / oxygenase $(r b c \mathrm{~L})$ sequences were added to a data set of all Bangiales (Sutherland et al. 2011) for phylogenetic confirmation of species identification. Smithora naiadum (C. L. Anderson) Hollenberg, Chlidophyllon kaspar (W. A. Nelson and N. M. Adams) W. A. Nelson and Pyrophyllon subtumens (J. Agardh ex R. M. Laing) W. A. Nelson, as members of the Erythropeltidales, were used as outgroups as in Sutherland et al. (2011).

Data sets were produced (for both COI and ITS) for our isolated Pythium and sequences downloaded from GenBank of "clade A" species of Pythium, a supported subclade within Pythium containing red alga pathogens (Robideau et al. 2011). P. insidiosum De Cock, Mendoza, Padhye, Ajello \& Kaufman, a member of Pythium clade C (Robideau et al. 2011), was used as an outgroup (Supplementary Table S2).

The phylogenetic tree for the Bangiales was constructed with maximum-likelihood (ML) using RAxML 7.2.8 (Stamatakis 2006) under the GTR + gamma model with partitioned codons. Support for individual nodes was determined by 400 bootstrap replicates. Phylogenetic trees for Pythium were constructed with ML and Bayesian inference (BI). ML analyses were performed using RAxML 7.2.8 under the GTR + gamma model, with codons parti- 
tioned for the COI data. Support for individual nodes was determined by 1,000 bootstrap replicates. BI analyses were conducted using MrBayes 3.2 (Ronquist et al. 2012) under the GTR + gamma model for 3 million generations with two independent runs, a sampling frequency of 1,000 and a burn-in of 300 trees.

\section{Species delimitation}

To delimit species in clade A, especially the species $P y$ thium chondricola and P. porphyrae, we used three methods: distance-based (Automatic Barcode Gap Discovery [ABGD], web last modified 17/09/2016) (Puillandre et al. 2012), a tree-based method (Poisson-Tree processes [PTP]) (Zhang et al. 2013) and a model-based method (Generalized Mixed Yule Coalescent [GMYC]) (Pons et al. 2006, Monaghan et al. 2009, Fujisawa and Barraclough 2013). All analyses were run with the COI and ITS datasets. ABGD was run with the following settings: $\mathrm{P}_{\min }=$ $0.001, \mathrm{P}_{\max }=0.1$, steps $=10, \mathrm{X}$ (relative gap width) $=1.0, \mathrm{Nb}$ bin (distance distribution) $=20$ and Jukes-Cantor (JC69) or Kimura (K80) parameter models. We used the Bayesian variant of the PTP method (bPTP). The current version of the software (Oct 2016) used our RAxML COI and ITS gene tree with 100,000 Markov chain Monte Carlo (MCMC) generations and thinning every 100 . The ultrametric tree for GMYC was generated with BEAST 1.8.2 (Drummond et al. 2012) from COI and ITS alignments after removing identical sequences. A coalescent constant size tree prior (Kingman 1982) was set under an uncorrelated lognormal relaxed clock and GTR + gamma + invariant sites model. The analysis was set up for 50 million generations and a sampling frequency of 5,000. Before performing the GMYC analyses, we checked the estimated samples size with Tracer 1.6 (Rambaut et al. 2014). The maximum clade credibility tree was computed using TreeAnnotator 1.8.3 (Drummond et al. 2012). The resulting ultrametric tree was imported into the GMYC web server, running the single threshold (sGMYC) (Pons et al. 2006).

\section{RESULTS}

\section{Molecular identification}

All tested species of Bangiales were identified by BLAST searches and phylogenetic analysis of $r b c \mathrm{~L}$, and were $100 \%$ identical to sequences already present in New Zealand and known from the Wellington area (Sutherland et al. 2011) (Supplementary Fig. S1). The only host of Pythi-

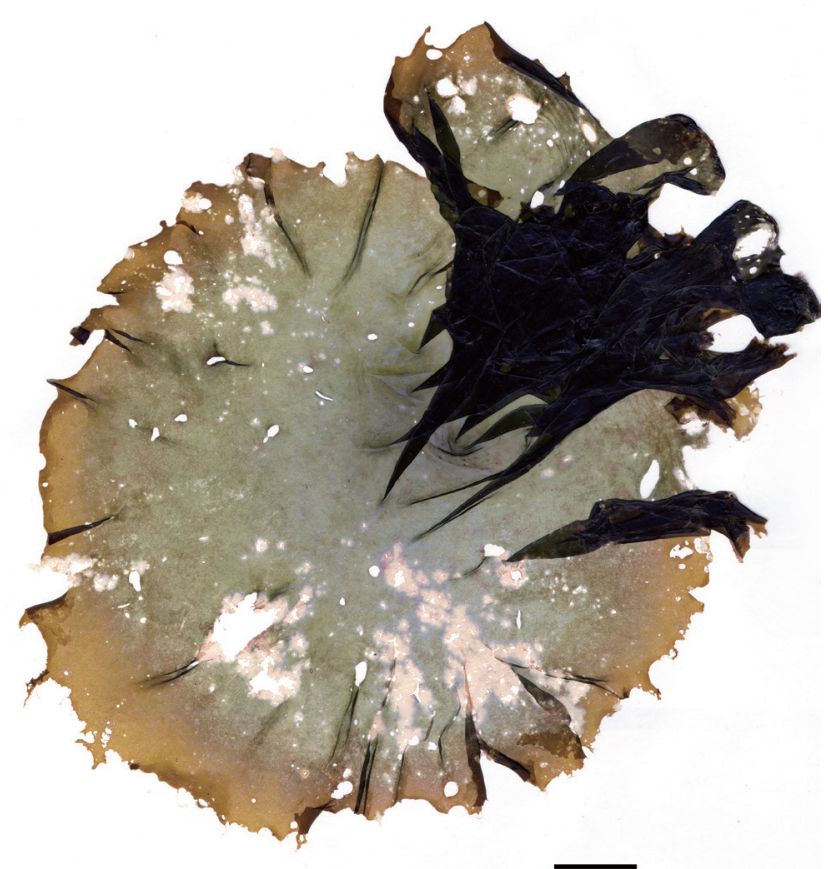

Fig. 1. Infected Pyropia plicata collected from Moa Point, New Zealand. The white-pink discolorations are caused by Pythium porphyrae. Scale bar represents: $2 \mathrm{~cm}$.

um porphyrae in Wellington was Pyropia plicata.

Samples of infected Pyropia were detected at Moa Point, especially in the austral winter month, Jun-Aug (Fig. 1). All collected Pythium samples from Moa Point (Supplementary Table S3) had identical COI (Genbank accession No. KY650705) and ITS (Genbank accession No. KY630550) sequences (i.e., sequences from blades and all Pythium cultures).

The phylogenetic analyses, both ML and BI, using ITS and COI showed that our samples formed a well-supported clade with Pythium chondricola, P. porphyrae, and $P$. adhaerens. In the COI analysis (Fig. 2) the support for this clade was high and this clade was a moderately supported sister clade (0.97 Bayesian PP) to P. monospermum. The level of variation within the P. adhaerens-P. chondricola-P. porphyrae clade was low. The ITS analysis was very similar (Fig. 3) and again showed a well-supported clade of $P$. adhaerens-P. chondricola-P. porphyrae. There was slight variation in $P$. adhaerens from the identical sequences of P. chondricola and P. porphyrae.

All three species delimitation methods, using the COI datasets, indicated five species, and placed P. chondricola, P. porphyrae, and P. adhaerens within the same putative genetic species (Fig. 2). The species delimitation results of the ITS datasets were very similar but both the PTP and AGBD methods separated P. adhaerens from P. chondri- 


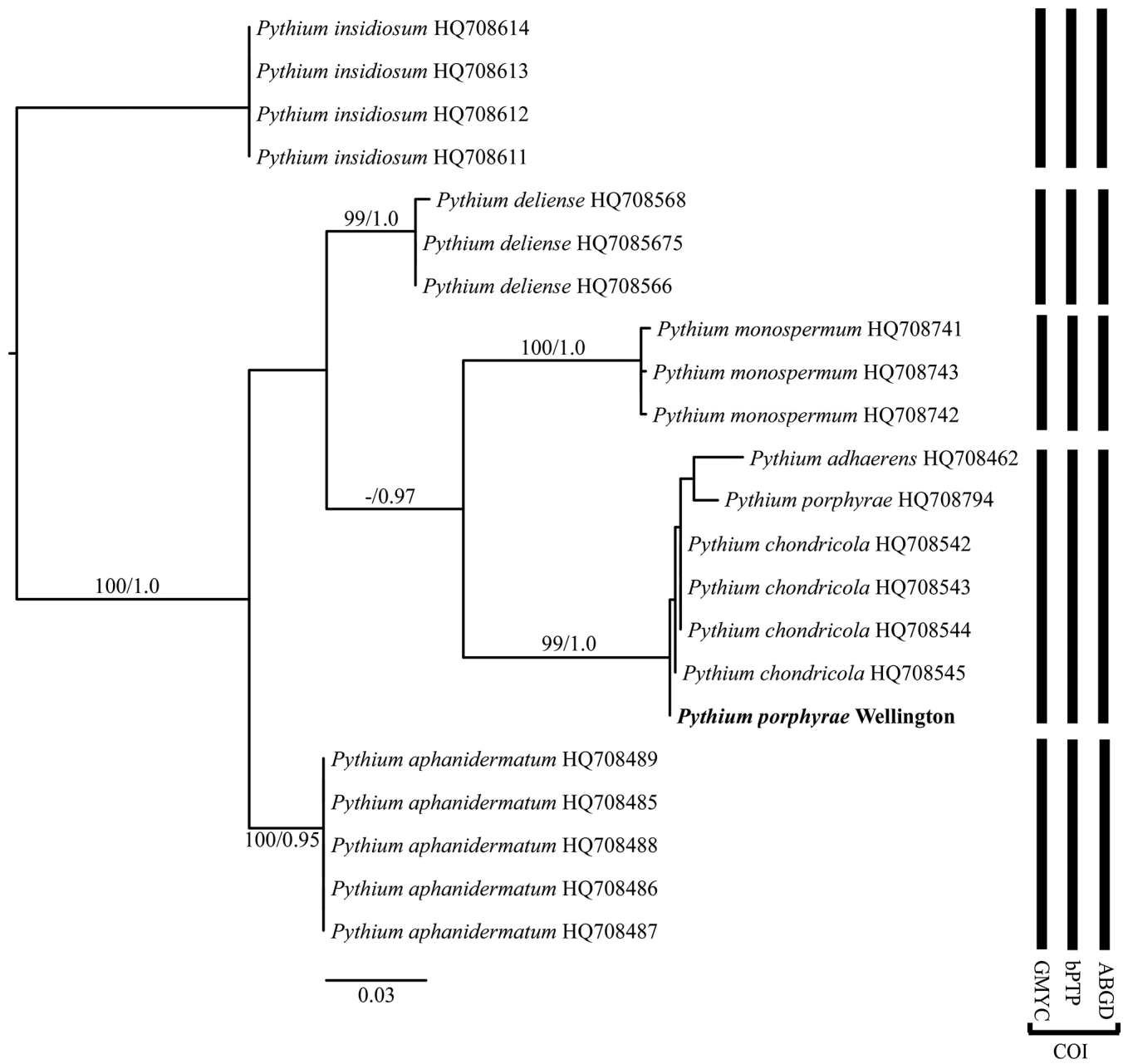

Fig. 2. Maximum likelihood (ML) phylogeny of Pythium species in "clade $A$ " based on the cytochrome oxidase subunit 1 (COI) gene sequences. Numbers on branches are ML bootstrap \% (BP) / Bayesian posterior probabilities (PP) values. Branches that had $<75 \%$ BP or $<0.90$ PP support are blank. Numbers beside names are GenBank accession numbers. Our wellington sample is in bold. Outgroup is Pythium insidiosum. The results of three species delimitation methods: Automatic Barcode Gap Discovery (ABGD), Bayesian variant of the Poisson-Tree processes (bPTP), and Generalized Mixed Yule Coalescent (GMYC) are indicated at the right of the tree. ITS, internal transcribed spacer of the rDNA cistron. Scale bar represents: nucleotides substitutions per site.

cola and P. porphyrae (Fig. 3).

The infection process of P. porphyrae on its host Pyropia plicata led to the dark coloration of infected cells and the quick spread of the infection, by hyphae, throughout the tissue (Fig. 4A-C). Pythium porphyrae isolated into culture media, produced hyphae between 2.5-5 $\mu$ m wide (Fig. 4D). On agar plates hyphae produced hyphal swellings (Fig. 4E). Although zoosporangia were not observed in our cultures we did see spores in the culture media that had germinated (Fig. 4F). Sexual reproduction was only observed a few times in Arasaki medium, oosporangia were smooth, occasionally slightly undulating, with one plerotic smooth oospore with a single antheridium (Fig. $4 G)$.

\section{Host specificity}

Several, both gametophytes and sporophytic 'conchocelis-stages,' of Bangiales, plus other algae were tested for infection with P. porphyrae (Table 1). The original host of P. porphyrae in Wellington, Pyropia plicata, was newly infected within $24 \mathrm{~h}$. After two weeks, an approximately $5 \times$ $5 \mathrm{~mm}$ piece of tissue was dead in our culture conditions. Other Pyropia and Porphyra species could be infected within less than $48 \mathrm{~h}$ (Fig. 5A-C). The infection process, while appearing slightly slower than that from the original host, was morphologically fairly similar (Fig. 5). Even after more than one week the gametophytic thalli of 'Bangia' 2 sp. BGA, 'Bangia' 1 sp. BMW, Champia novae-zea- 


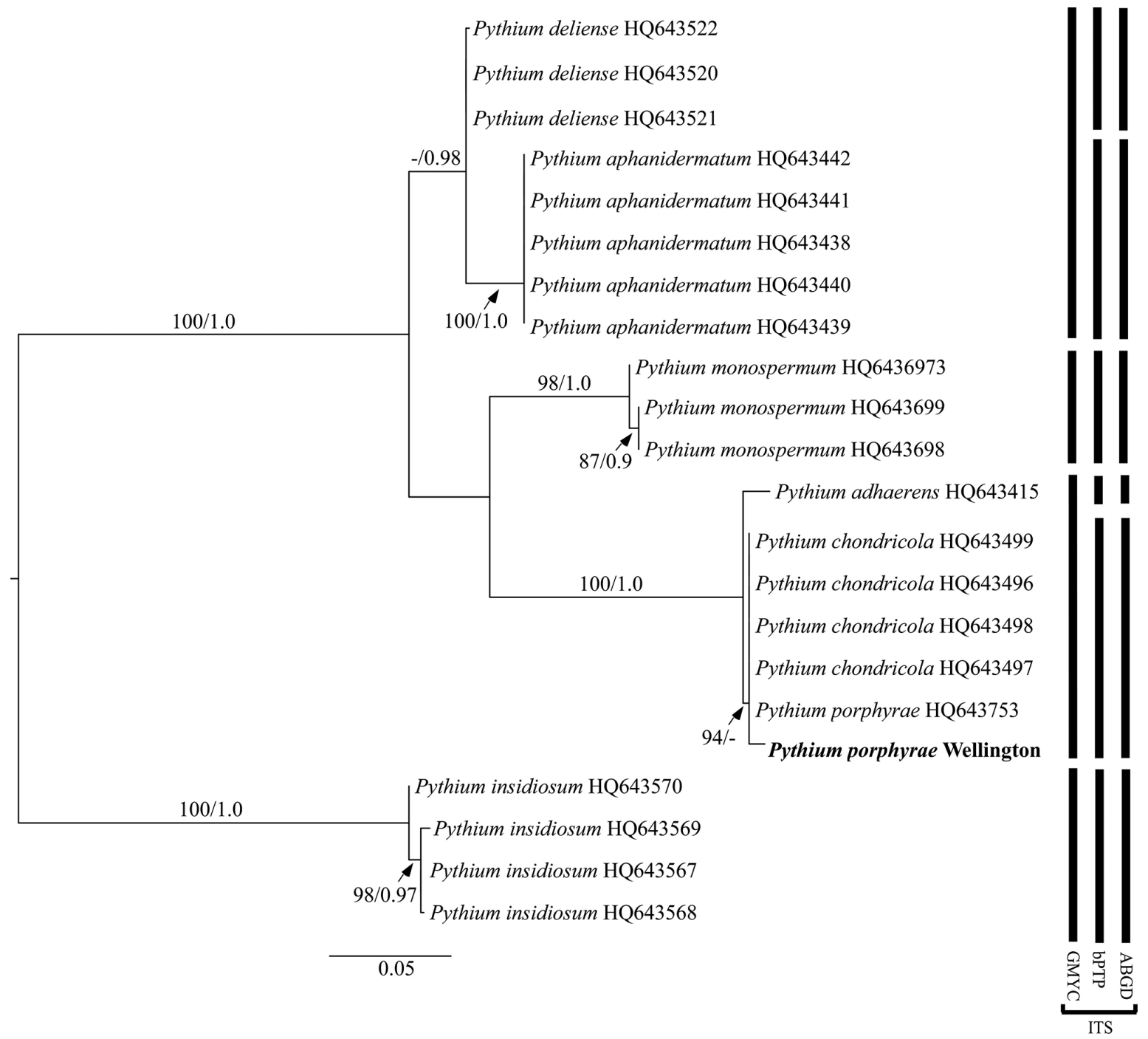

Fig. 3. Maximum likelihood (ML) phylogeny of Pythium species in "clade $A$ " based on the internal transcribed spacer of the rDNA cistron (ITS) sequences. Numbers on branches are ML bootstrap \% (BP) / Bayesian posterior probabilities (PP) values. Branches that had $<75 \%$ BP or $<0.90 \mathrm{PP}$ support are blank. Numbers beside names are GenBank accession numbers. Our wellington sample is in bold. Outgroup is Pythium insidiosum. The results of three species delimitation methods: Automatic Barcode Gap Discovery (ABGD), Bayesian variant of the Poisson-Tree processes (bPTP), and Generalized Mixed Yule Coalescent (GMYC) are indicated at the right of the tree. Scale bar represents: nucleotides substitutions per site. 


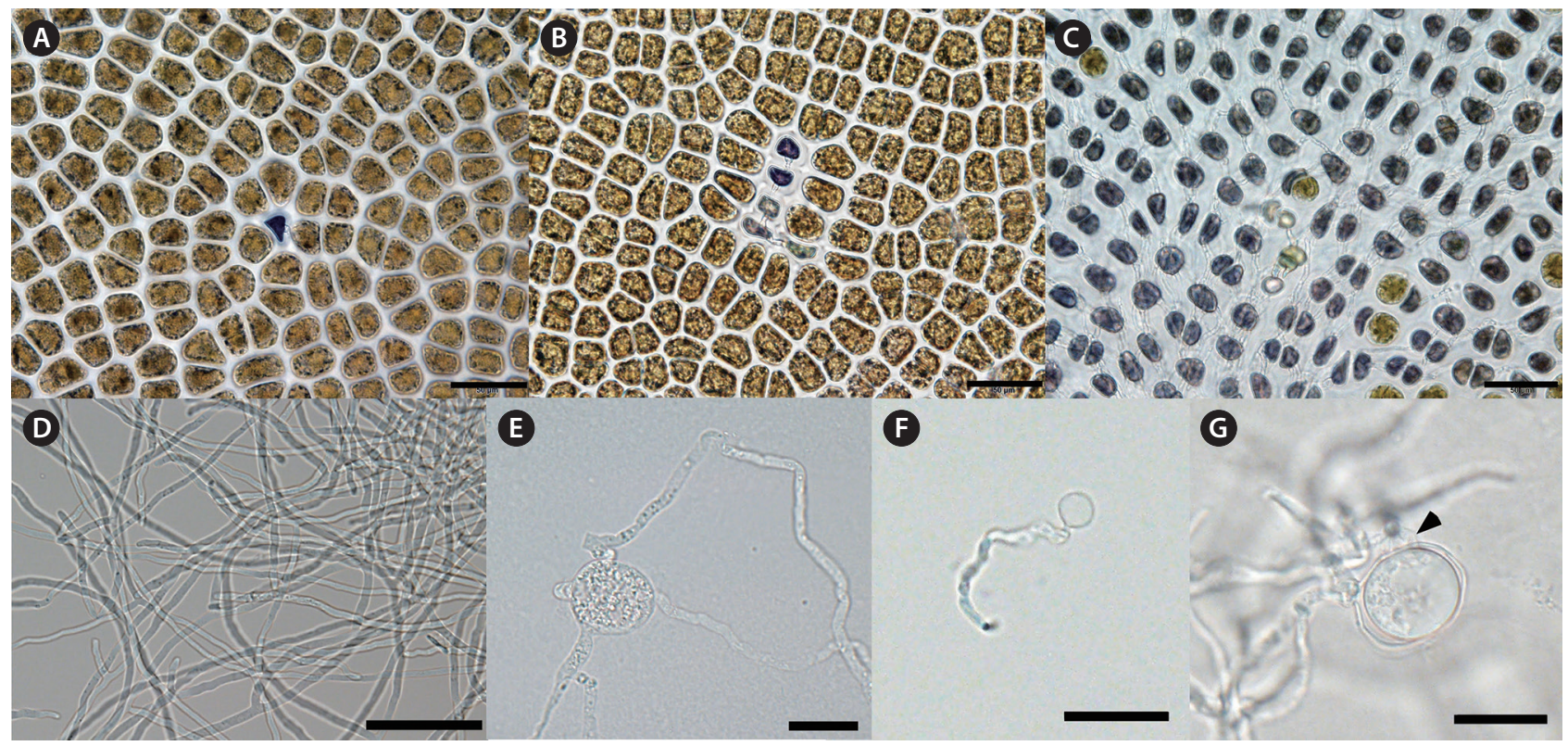

Fig. 4. Pythium porphyrae in culture. (A-C) Infected cellsof Pyropia plicata after 1 day (A), 3 days (B), and 9 days (C). Dark cells are newly infected, light cells were older infected cells, after 9 days almost all cells are dead. P. porphyrae hyphae between cells visible. (D) Free hyphae in Arasaki B Medium. (E) Hyphae swelling. (F) Germinating spore, with emergent germ tube and empty spore body. (G) Oogonium, with a single oospore, with attached antheridium (arrowhead). Scale bars represent: A-D \& F, $50 \mu \mathrm{m} ; \mathrm{E} \& \mathrm{G}, 20 \mu \mathrm{m}$.

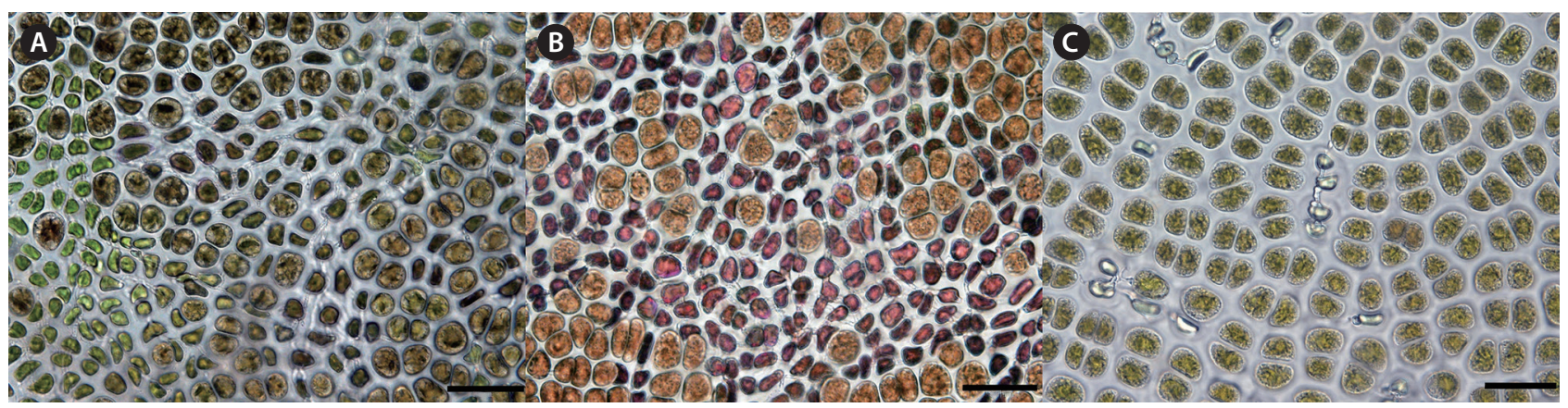

Fig. 5. Infection of Pythium porphyrae on different Bangiales. (A) Infection of Pyropia virididentata. (B) Infection of Pyropia cinnamomea. (C) Infection on Porphyra LGD030. Scale bars represent: A-C, $50 \mu \mathrm{m}$. 
landiae, Bostrychia arbuscula, and Ulva sp., showed no infection with P. porphyrae (Table 1). We did not get any observable infection in any conchocelis phases.

\section{DISCUSSION}

All Pythium found and isolated in Wellington had identical COI and ITS sequences. These sequences were identical to the type culture of $P$. chondricola, isolated from Chondrus crispus in the Netherlands and very similar to sequences of $P$. porphyrae. Our species delimitation methods indicate that P. chondricola, P. porphyrae, and $P$. adhaerens are either the same species (COI analysis), or P. adhaerens is possibly a different species (ITS analysis). Also morphologically, no substantial difference can be seen between descriptions of $P$. chondricola, P. porphy- rae, and our isolate from New Zealand (Table 2). Correct species identification is critical for all further biological analysis. For example, if two pathogens are recognized on cultivated Pyropia (Pythium porphyrae and P. chondricola) (e.g., Kim et al. 2014, Lee et al. 2015), this could interfere with efforts in understanding, and controlling, the infection process. Our molecular data also indicates that the Pyropia pathogen in New Zealand is genetically identical, or very similar, to samples growing on crops in the northern hemisphere (Korea, Japan). We believe that the molecular similarity with these markers, the grouping into a single species using several molecular species delimitation methods, including samples from Japan, plus the lack of robust characters to separate the two species indicates that they should be placed in taxonomic synonymy.

Table 1. Hosts tested for specificity of Pythium porphyrae

\begin{tabular}{|c|c|c|}
\hline Species & $\begin{array}{l}\text { Conchocelis } \\
\text { infection }\end{array}$ & $\begin{array}{c}\text { Gametophyte } \\
\text { infection }\end{array}$ \\
\hline Pyropia plicata W. A. Nelson & - & + \\
\hline Pyropia suborbiculata (Kjellm.) J. E. Sutherland, H. H. Choi, M. S. Hwang \& W. A. Nelson & - & + \\
\hline Pyropia virididentata (W. A. Nelson) W. A. Nelson & - & + \\
\hline Pyropia cinnamomea (W. A. Nelson) W. A. Nelson & - & + \\
\hline Pyropia columbina (Montagne) W. A. Nelson & - & l \\
\hline Pyropia rakiura (W. A. Nelson) W. A. Nelson & - & I \\
\hline Porphyra sp. GRB145, Sutherland et al. 2011 & - & + \\
\hline Porphyra sp. LDG030, Sutherland et al. 2011 & - & + \\
\hline Clymene sp. OTA, Sutherland et al. 2011 & - & l \\
\hline 'Bangia' 1 sp. BFK, Sutherland et al. 2011 & - & l \\
\hline 'Bangia' 1 sp. BMW, Sutherland et al. 2011 & I & - \\
\hline 'Bangia' 2 sp. BGA, Sutherland et al. 2011 & - & - \\
\hline Champia novae-zealandiae (J. D. Hooker \& Harvey) Harvey & I & - \\
\hline Bostrychia arbuscula Harvey & I & - \\
\hline Ulva sp. & I & - \\
\hline
\end{tabular}

+ , infected cells seen in previously uninfected tissue; -, no infected cells seen; /, not tested.

Table 2. Morphological character comparison between Pythium porphyrae from New Zealand (NZ) and type species descriptions of P. porphyrae and $P$. chondricola

\begin{tabular}{|c|c|c|c|}
\hline & NZ specimens & P. porphyrae & P. chondricola \\
\hline Hyphae (dia.) $(\mu \mathrm{m})$ & $2.5-5$ & $2.2-4.4$ & $4(2.5-6)$ \\
\hline Hyphal swellings & Present & Present $^{\mathrm{a}}$ & Present \\
\hline Zoospores per sporangium & Not seen & $6-17$ & Not reported \\
\hline Oogonium, shape and position & $\begin{array}{l}\text { Smooth (rarely undulating), } \\
\text { intercalary }\end{array}$ & $\begin{array}{l}\text { Smooth, intercalary, occasion- } \\
\text { ally terminal }\end{array}$ & $\begin{array}{l}\text { Smooth (rarely undulating), in- } \\
\text { tercalary, occasionally terminal }\end{array}$ \\
\hline Antheridia per oogonium & 1 & $1-4$ & $1-3(-4)$ \\
\hline Oospore, type and diameter $(\mu \mathrm{m})$ & Plerotic, 19-22 & Plerotic, 13.2-17.4 & $\begin{array}{l}\text { Plerotic, occasionally aplerotic, } \\
16-24\end{array}$ \\
\hline Reference & & Takahashi et al. (1977) & De Cock (1986) \\
\hline
\end{tabular}

${ }^{a}$ Described as conidia in Takahashi et al. (1977), see Figs 1-6. 
Pythium porphyrae M. Takah \& M. Sasaki (1977). Transaction of the Mycological Society of Japan 18:279-285.

Heterotypic synonym: Pythium chondricola De Cock (1986). Mycotaxon 25:102, Fig. 1a-i.

The geographic range of Pythium porphyrae is now from the northern Atlantic to the northern and southern Pacific Oceans. This wide distribution, without any obvious biogeographic patterns and little or no genetic variation in standard molecular markers could indicate that this micro-organism, disperses easily and is truly ubiquitous (Fenchel and Finlay 2004). The host range is also varied, while infecting various genera and species of New Zealand Bangiales (Pyropia, Porphyra), we did not detect infections, other than on Pyropia plicata, in our population at Moa Point. It is possible that the virulence of Pythium porphyrae on other species is reduced, as the slower infection in culture suggests, and therefore not readily detected. Our isolate also did not infect filamentous gametophytic Bangiales ("Bangia") nor any filamentous sporophytic phases ('conchocelis') which has been suggested before based on infection of Pythium marinum Sparrow (Kerwin et al. 1992), a species in clade B of Pythium (Lévesque and De Cock 2004). The cell wall composition of conchocelis phases is known to differ from the gametophytes (Mukai et al. 1981, Vreeland and Kloareg 2000), and carbohydrates are known to be important in spore attachment and penetration in P. porphyrae (Uppalapati and Fujita 2000). In our experiments, $P$. porphyrae was not able to infect members of the Florideophyceae, while the original collection of $P$. chondricola was from decaying red algae (e.g., Chrondrus crispus) but it is unclear if Pythium was a necrotroph or a saprotroph from the original descriptions (De Cock 1986). The full host range of this species in the field needs to be further investigated, while its host range in culture is known to be great, even infecting land plants (Klochkova et al. 2016a).

Our genetic species delimitation methods indicate that $P$. adhaerens may be conspecific with $P$. chondricola and $P$. porphyrae, although some species delimitation methods (ABGD, PTP) using ITS data indicate distinct species for $P$. adhaerens from P. chondricola-P. porphyrae. P. adhaerens was first described by Sparrow (1931) on the freshwater green alga Rhizoclonium hieroglyphicum (C. Agardh) Kützing, and it has been reported from land plants (sugar beet, maize, pea, tomato, and cucumber) (Sparrow 1932). Whether it is a distinct species, able to tolerate marine environments needs further study.

\section{ACKNOWLEDGEMENTS}

We thank Wendy Nelson (National Institute of Water and Atmospheric Research, Wellington, New Zealand) for providing the conchocelis-stage cultures of the Bangiales. This research was supported by the Golden Seed Project, Ministry of Oceans and Fisheries (Republic of Korea) to GHK.

\section{SUPPLEMENTARY MATERIAL}

Supplementary Table S1. Detailed overview of hosts tested for specificity with Pythium porphyrae (http:// www.e-algae.org).

Supplementary Table S2. Pythium samples used for ITS and COI trees from Genbank, with accession numbers (http://www.e-algae.org).

Supplementary Table S3. Pythium porphyrae collections from Wellington, New Zealand placed into culture, plus host and collection date (http:/ /www.e-algae.org).

Supplementary Fig. S1. Maximum-likelihood phylogeny of all Bangiales from Sutherland et al. (2011) based on $r b c \mathrm{~L}$ gene sequences. Samples used in infection with Pythium porphyrae experiments identified (marked with red boxes). Outgroups removed for clarity (http://www.ealgae.org).

\section{REFERENCES}

Arasaki, S. 1947. Studies on the rot of Porphyra tenera by a Pythium. Nippon Suisan Gakkaishi 13:74-90.

Arasaki, S., Akino, K. \& Tomiyama, T. 1968. A comparison of some physiological aspects in a marine Pythium on the host and on the artificial medium. Bull. Misaki Mar. Biol. Inst. Kyoto Univ. 12:203-206.

Blouin, N. A., Brodie, J. A., Grossman, A. C., Xu, P. \& Brawley, S. H. 2011. Porphyra: a marine crop shaped by stress. Trends Plant Sci. 16:29-37.

De Cock, A. W. A. M. 1986. Marine Pythiaceae from decaying seaweeds in the Netherlands. Mycotaxon 25:101-110.

De la Bastide, P. Y., Leung, W. L. \& Hintz, W. E. 2015. Species composition of the genus Saprolegnia in fin fish aquaculture environments, as determined by nucleotide sequence analysis of the nuclear rDNA ITS regions. Fungal Biol. 119:27-43.

Ding, H. \& Ma, J. 2005. Simultaneous infection by red rot and chytrid diseases in Porphyra yezoensis Ueda. J. Appl. Phycol. 17:51-56. 
Drummond, A. J., Suchard, M. A., Xie, D. \& Rambaut, A. 2012. Bayesian phylogenetics with BEAUti and the BEAST 1.7. Mol. Biol. Evol. 29:1969-1973.

FAO FishStat, Chen, J. \& Xu, P. 2016. Cultured Aquatic Species Information Programme. Porphyra spp. Available from: http://www.fao.org/fishery/culturedspecies/Porphyra spp/en. Accessed Oct 20, 2016.

Fenchel, T. \& Finlay, B. J. 2004. The ubiquity of small species: patterns of local and global diversity. BioScience 54:777784.

Food and Agriculture Organization of the United Nations. 2014. The state of world fisheries and aquaculture: opportunities and challenges. Food and Agriculture Organization of the United Nations, Rome, $223 \mathrm{pp}$.

Francis, M. M., Webb, V. \& Zuccarello, G. C. 2016. Marine yeast biodiversity on seaweeds in New Zealand waters. N. Z. J. Bot. 54:30-47.

Freshwater, D. W. \& Rueness, J. 1994. Phylogenetic relationships of some European Gelidium (Gelidiales, Rhodophyta) species, based on $r b c \mathrm{~L}$ nucleotide sequence analysis. Phycologia 33:187-194.

Fujisawa, T. \& Barraclough, T. G. 2013. Delimiting species using single-locus data and the generalized mixed yule coalescent approach: a revised method and evaluation on simulated data sets. Syst. Biol. 62:707-724.

Gachon, C. M. M., Sime-Ngando, T., Strittmatter, M., Chambouvet, A. \& Kim, G. H. 2010. Algal diseases: spotlight on a black box. Trends Plant Sci. 15:633-640.

Goff, L. J. \& Moon, D. A. 1993. PCR amplification of nuclear and plastid genes from algal herbarium specimens and algal spores. J. Phycol. 29:381-384.

Kageyama, K. 2014. Molecular taxonomy and its application to ecological studies of Pythium species. J. Gen. Plant Pathol. 80:314-326.

Kawamura, Y., Yokoo, K., Tojo, M. \& Hishiike, M. 2005. Distribution of Pythium porphyrae, the causal agent of red rot disease of Porphyrae spp., in the Ariake Sea, Japan. Plant Dis. 89:1041-1047.

Kearse, M., Moir, R., Wilson, A., Stones-Havas, S., Cheung, M., Sturrock, S., Buxton, S., Cooper, A., Markowitz, S., Duran, C., Thierer, T., Ashton, B., Meintjes, P. \& Drummond, A. 2012. Geneious Basic: an integrated and extendable desktop software platform for the organization and analysis of sequence data. Bioinformatics 28:16471649.

Kerwin, J. L., Johnson, L. M., Whisler, H. C. \& Tuininga, A. R. 1992. Infection and morphogenesis of Pythium marinum in species of Porphyra and other red algae. Can. J. Bot. 70:1017-1024.

Kim, G. H., Kochkova, T. A., Lee, D. J. \& Im, S. H. 2016. Chlo- roplast virus causes green-spot disease in cultivated $P y$ ropia of Korea. Algal Res. 17:293-299.

Kim, G. H., Moon, K. -H., Kim, J. -Y., Shim, J. \& Klochkova, T. A. 2014. A revaluation (sic) of algal diseases in Korean Pyropia (Porphyra) sea farms and their economic impact. Algae 29:249-265.

Kim, M. S., Kim, S. Y. \& Nelson, W. 2010. Symphyocladia lithophila sp. nov. (Rhodomelaceae, Ceramiales), a new Korean red algal species based on morphology and $r b c \mathrm{~L}$ sequences. Bot. Mar. 53:233-241.

Kingman, J. F. C. 1982. The coalescent. Stoch. Process Their Appl. 13:235-248.

Klochkova, T. A., Jung, S. \& Kim, G. H. 2016a. Host range and salinity tolerance of Pythium porphyrae may indicate its terrestrial origin. J. Appl. Phycol. https://doi. org/10.1007/s10811-016-0947-8.

Klochkova, T. A., Shim, J. B., Hwang, M. S. \& Kim, G. H. 2012. Host-parasite interactions and host species susceptibility of the marine oomycete parasite, Olpidiopsis sp., from Korea that infects red algae. J. Appl. Phycol. 24:135-144.

Klochkova, T. A., Shin, Y. J., Moon, K. -H., Motomura, T. \& Kim, G. H. 2016b. New species of unicellular obligate parasite, Olpidiopsis pyropiae sp. nov., that plagues $P y$ ropia sea farms in Korea. J. Appl. Phycol. 28:73-83.

Lee, S. J., Hwang, M. S., Park, M. A., Baek, J. M., Ha, D. -S., Lee, J. E. \& Lee, S. R. 2015. Molecular identification of the algal pathogen Pythium chondricola (Oomycetes) from Pyropia yezoensis (Rhodophyta) using ITS and cox 1 markers. Algae 30:217-222.

Leliaert, F., Verbruggen, H., Vanormelingen, P., Steen, F., López-Bautista, J. M., Zuccarello, G. C. \& De Clerck, O. 2014. DNA-based species delimitation in algae. Eur. J. Phycol. 49:179-196.

Lévesque, C. A. \& De Cock, A. W. A. M. 2004. Molecular phylogeny and taxonomy of the genus Pythium. Mycol. Res. 108:1363-1383.

Monaghan, M. T., Wild, R., Elliot, M., Fujisawa, T., Balke, M., Inward, D. J. G., Lees, D. C., Ranaivosolo, R., Eggleton, P., Barraclough, T. G. \& Vogler, A. P. 2009. Accelerated species Inventory on Madagascar using coalescent-based models of species delineation. Syst. Biol. 58:298-311.

Mukai, L. S., Craigie, J. S. \& Brown, R. G. 1981. Chemical composition and structure of the cell walls of the conchocelis and thallus phases of Porphyra tenera (Rhodophyceae). J. Phycol. 17:192-198.

Nelson, W. A., Farr, T. J. \& Broom, J. E. S. 2006. Phylogenetic relationships and generic concepts in the red order Bangiales: challenges ahead. Phycologia 45:249-259.

Park, C. S., Sakaguchi, K., Kakinuma, M. \& Amano, H. 2000. Comparison of the morphological and physiological 
features of the red rot disease fungus Pythium sp. isolated from Porphyra yezoensis from Korea and Japan. Fish. Sci. 66:261-269.

Patterson, D. J. 1989. Stramenopiles: chromophytes from a protistan perspective. In Green, J. C., Leadbeater, B. S. C. \& Diver, W. L. (Eds.) The Chromophyte Algae: Problems and Perspectives, Systematics Association Special Vol. 38. Clarendon Press, Oxford, pp. 357-379.

Pons, J., Barraclough, T. G., Gomez-Zurita, J., Cardoso, A., Duran, D. P., Hazell, S., Kamoun, S., Sumlin, W. D. \& Vogler, A. P. 2006. Sequence-based species delimitation for the DNA taxonomy of undescribed insects. Syst. Biol. 55:595-609.

Puillandre, N., Lambert, A., Brouillet, S. \& Achaz, G. 2012. ABGD, Automatic Barcode Gap Discovery for primary species delimitation. Mol. Ecol. 21:1864-1877.

Rambaut, A., Suchard, M. A., Xie, D. \& Drummond, A. J. 2014. Tracer v1.6. Available from: http://beast.bio.ed.ac.uk/ Tracer/. Accessed Feb 3, 2017.

Robideau, G. P., De Cock, A. W. A. M., Coffey, M. D., Voglmayr, H., Brouwer, H., Bala, K., Chitty, D. W., Désaulniers, N., Eggertson, Q. A., Gachon, C. M. M., Hu, C. -H., Küpper, F. C., Rintoul, T. L., Sarhan, E., Verstappen, E. C. P., Zhang, Y., Bonants, P. J. M., Ristaino, J. B. \& Lévesque, C. A. 2011. DNA barcoding of oomycetes with cytochrome $c$ oxidase subunit I and internal transcribed spacer. Mol. Ecol. Resour. 11:1002-1011.

Ronquist, F., Teslenko, M., Van Der Mark, P., Ayres, D. L., Darling, A., Höhna, S., Larget, B., Liu, L., Suchard, M. A. \& Huelsenbeck, J. P. 2012. MrBayes 3.2: efficient Bayesian phylogenetic inference and model choice across a large model space. Syst. Biol. 61:539-542.

Sandoval-Sierra, J. V., Martín, M. P. \& Diéguez-Uribeondo, J. 2014. Species identification in the genus Saprolegnia (Oomycetes): defining DNA-based molecular operational taxonomic units. Fungal Biol. 118:559-578.

Sparrow, F. K. Jr. 1931. Two new species of Pythium parasitic on green algae. Ann. Bot. 45:257-277.
Sparrow, F. K. Jr. 1932. Observations on the parasitic ability of certain species of Pythium. Phytopathology 22:385-390.

Stamatakis, A. 2006. RAxML-VI-HPC: maximum likelihoodbased phylogenetic analyses with thousands of taxa and mixed models. Bioinformatics 22:2688-2690.

Sutherland, J. E., Lindstrom, S. C., Nelson, W. A., Brodie, J., Lynch, M. D. J., Hwang, M. S., Choi, H. -G., Miyata, M., Kikuchi, N., Oliveira, M. C., Farr, T., Neefus, C., MolsMortensen, A., Milstein, D. \& Müller, K. M. 2011. A new look at an ancient order: generic revision of the Bangiales (Rhodophyta). J. Phycol. 47:1131-1151.

Takahashi, M., Ichitani, T. \& Sasaki, M. 1977. Pythium porphyrae Takahashi et Sasaki, sp. nov. causing red rot of marine algae Porphyra spp. Trans. Mycol. Soc. Jpn. 18:279-285.

Uppalapati, S. R. \& Fujita, Y. 2000. Carbohydrate regulation of attachment, encystment, and appressorium formation by Pythium porphyrae (Oomycota) zoospores on Porphyra yezoensis (Rhodophyta). J. Phycol. 36:359-366.

Vreeland, V. \& Kloareg, B. 2000. Cell wall biology in red algae: divide and conquer. J. Phycol. 36:793-797.

West, J. A. \& McBride, D. L. 1999. Long-term and diurnal carpospore discharge patterns in the Ceramiaceae, Rhodomelaceae and Delesseriaceae (Rhodophyta). Hydrobiologia 398/399:101-113.

White, T. J., Bruns, T., Lee, S. \& Taylor, J. 1990. Amplification and direct sequencing of fungal ribosomal RNA genes for phylogenetics. In Innis, M. A., Gelfand, D. H., Sninsky, J. J. \& White, T. J. (Eds.) PCR Protocols: A Guide to Methods and Applications. Academic Press, New York, NY, pp. 315-322.

Zhang, J., Kapli, P., Pavlidis, P. \& Stamatakis, A. 2013. A general species delimitation method with applications to phylogenetic placements. Bioinformatics 29:2869-2876.

Zuccarello, G. C. \& Lokhorst, G. M. 2005. Molecular phylogeny of the genus Tribonema (Xanthophyceae) using $r b c \mathrm{~L}$ gene sequence data: monophyly of morphologically simple algal species. Phycologia 44:384-392. 